\title{
Binding of serum ferritin to concanavalin A in patients with iron overload and with chronic liver disease
}

\author{
RWG CHAPMAN, A GORMAN, M LAULICHT, MA HUSSAIN, \\ SHEILA SHERLOCK, AV HOFFBRAND
}

From the Departments of Haematology and Medicine, Royal Free Hospital, Pond Street, Hampstead, London NW3 2QG

SUMMARY Total serum ferritin and the proportion of serum ferritin binding to concanavalin A (glycosylated ferritin) was measured in 18 healthy volunteers and in 84 patients, eight with primary haemochromatosis, 43 with $\beta$-thalassaemia major and secondary iron overload and 33 with chronic liver diseases without iron overload.

The total serum ferritin was either equally or even more closely related than either the non-binding or the concanavalin A binding ferritin, to the liver iron concentration in all patients with iron overload, and with the units of blood transfused in non-chelated thalassaemic patients.

The total serum ferritin showed a significant correlation with serum aminotransferase for the group of 84 patients. In the thalassaemic patients the ferritin binding to concanavalin A also correlated with aminotransferase. However, in the other groups it was the ferritin not binding to concanavalin A which showed a significant correlation with aminotransferase activity.

These results suggest that measuring the fraction of serum ferritin which binds to concanavalin A does not offer any advantage over estimation of the total serum ferritin concentration in the assessment of iron stores in patients with iron overload and liver damage.

Serum ferritin is directly related to body iron stores in normal human subjects. ${ }^{1}$ However, raised concentrations of serum ferritin are found in some diseases when body iron stores are not increased, as in acute and chronic liver damage, ${ }^{2}$ malignancy and infections. ${ }^{3}$

The majority of isoferritins present in normal human serum bind to the lectin concanavalin $\mathrm{A}$. It has been suggested that ferritin released from damaged tissue does not bind to concanavalin A while ferritin secreted from reticuloendothelial cells is glycosylated, binds to concanavalin A and may provide a more accurate estimate of body iron stores than total serum ferritin. ${ }^{4}$

We have measured the binding of human serum ferritin to concanavalin A, using sera from healthy volunteers, patients with primary and secondary iron overload and patients with chronic liver disease. The aim of the study was to assess the value of

RWGC was Watson Smith Research Fellow of the Royal College of Physicians of London.

Accepted for publication 14 September 1981 measuring free and glycosylated serum ferritin separately in interpreting raised serum ferritin values as a measure of body iron stores, in patients with iron overload and patients with chronic liver disease.

\section{Patients and methods}

Serum samples were obtained from 18 healthy blood donors; eight untreated patients with primary haemochromatosis and 43 patients with $\beta$-thalassaemia major who were receiving regular blood transfusions. Twenty-three of the thalassaemic patients had been treated with subcutaneous desferrioxamine and oral ascorbic acid for between six months and two years. In addition, serum samples were obtained from 21 patients with chronic alcoholic liver disease (alcoholic hepatitis and cirrhosis), seven with primary biliary cirrhosis and five with chronic active hepatitis.

Serum ferritin concentrations were determined by immunoradiometric assay. ${ }^{5}$ The total serum ferritin was raised above control values in all 84 patients included in this study. Binding of ferritin to concanavalin A was measured by incubation of 481 
Table 1 Laboratory data from the sera and liver biopsy tissue from patients with iron overload and liver disease

\begin{tabular}{|c|c|c|c|c|c|c|c|}
\hline \multirow[t]{2}{*}{ Patients } & \multicolumn{3}{|c|}{ Total serum ferritin $(\mu g / l)$} & \multicolumn{3}{|c|}{ Serum aminotransferase $(I U / I)$} & $\overline{\bar{\omega}}$ \\
\hline & No & $M e a n \pm S E M$ & Range & No & Mean $\pm S E M$ & Range & 을 \\
\hline $\begin{array}{l}\text { Thalassaemia major } \\
\text { Primary haemochromatosis } \\
\text { Alcoholic liver disease } \\
\text { Primary biliary cirrhosis } \\
\text { Chronic active hepatitis } \\
\text { Laboratory reference range }\end{array}$ & $\begin{array}{r}43 \\
8 \\
21 \\
7 \\
5\end{array}$ & $\begin{array}{r}5741 \pm 791 \\
1870 \pm 414 \\
1118 \pm 146 \\
585 \pm 70 \\
738 \pm 231\end{array}$ & $\begin{array}{l}440-23000 \\
540-4200 \\
360-2520 \\
380-940 \\
340-1600 \\
\text { F } 15-150 \\
\text { M } 40-340\end{array}$ & $\begin{array}{r}43 \\
8 \\
21 \\
7 \\
5\end{array}$ & $\begin{array}{l}47.6 \pm 5.0 \\
37.9 \pm 9.3 \\
61.9 \pm 14.3 \\
77.0 \pm 9.0 \\
32.8 \pm 6.4\end{array}$ & $\begin{array}{r}11-133 \\
9-83 \\
11-310 \\
47-115 \\
19-57 \\
5-15\end{array}$ & 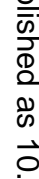 \\
\hline
\end{tabular}

serum with concanavalin A-Sepharose 4B, and subsequent separation of bound and free ferritin by centrifugation. ${ }^{4}$

Serum aminotransferase (aspartate transaminase) was measured on the same day as serum ferritin. Serum iron and total iron binding capacity were measured by the method recommended by the ICSH. ${ }^{6}$

Leucocyte ascorbic acid concentrations were estimated in 27 thalassaemic patients by the method of Denson and Bowers. ${ }^{7}$ Hepatitis B surface antigen (HBsAg) was present in the sera of three of 43 thalassaemic patients, measured by radioimmunoassay. The other 33 patients in the study were HBsAg-negative. Hepatitis B surface antibody (HBsAb) was present in the sera of seven of eight thalassaemic patients tested, measured by radioimmunoassay.

Liver biopsies were performed percutaneously using a Menghini needle and assessed histologically. The iron content was graded according to the criteria of Scheuer et al. ${ }^{8}$ Liver biopsies were performed in all 33 patients with chronic liver disease, and all 33 showed less than grade I siderosis. Seven of eight patients with primary haemochromatosis and eight of 43 patients with thalassaemia major who were all ascorbic acid replete, had liver biopsies performed. The chemical liver iron concentration was measured in these and 10 of the alcoholic patients by the method of Barry and Sherlock. ${ }^{9}$

The data were analysed using parametric statistical methods. The differences between the means of the groups were analysed using analysis of variance and Tukey's $t$ test.

\section{Results}

The results of the laboratory investigations are shown in Table 1. The total, unbound (or free), and bound serum ferritin were each compared with the serum aminotransferase (AST) used as an estimate of liver cell damage, the units of blood transfused and the chemical liver iron concentration, used as an index of total body iron stores (Table 2). In addition the percentage free ferritin (free ferritin $\times 100$ divided by the total ferritin) and ferritin:AST ratio (total serum ferritin divided by the AST) were calculated and compared with liver iron concentration and AST (Table 2).

\section{SERUM AST}

In every group the total serum ferritin concentration correlated positively with the AST (Table 2), apart from the patients with primary biliary cirrhosis in whom there was a tendency to significance $(0 \cdot 1>$ $p>0.05$ ). In the thalassaemic patients the bound serum ferritin concentration also correlated significantly with the AST but the free ferritin concentration did not. On the other hand, in the other groups including the patients with primary haemochromatosis, it was the free serum ferritin, not the bound, which correlated with the AST.

\section{UNITS OF BLOOD TRANSFUSED}

In the 20 thalassaemic patients who had not received chelation therapy the total, free and bound ferritin each correlated with the units of blood transfused (Figs 1-3). Neither the bound nor free ferritin correlated more closely than the total ferritin, in these non-chelated patients (Table 2).

\section{LIVER IRON CONCENTRATION}

The total ferritin correlated with the liver iron concentration in the patients with primary haemochromatosis, and in ascorbic acid-replete thalassaemic patients, but no correlation was observed for the patients with alcoholic liver disease. However, while the bound ferritin correlated with liver iron concentration for the thalassaemic patients, in the primary haemochromatosis group it was the free ferritin, not bound, which showed a positive correlation.

\section{$\%$ FREE SERUM FERRITIN}

No significant difference was observed between the mean free ferritin (expressed as a percentage) in the sera of the patients with primary or secondary 


\begin{tabular}{|c|c|c|c|c|c|c|c|c|}
\hline \multicolumn{3}{|c|}{ liver iron concentration ( $\mu \mathrm{g} / 100 \mathrm{mg} d r y \mathrm{wt})$} & \multicolumn{3}{|c|}{ Free ferritin $(\mu g / l)$} & \multicolumn{3}{|c|}{ Bound ferritin $(\mu \mathrm{g} / \mathrm{l})$} \\
\hline No & Mean $\pm S E M$ & Range & No & Mean $\pm S E M$ & Range & No & Mean $\pm S E M$ & Range \\
\hline $\begin{array}{c}8 \\
7 \\
0 \\
\text { ND } \\
\text { ND }\end{array}$ & $\begin{array}{r}1877 \pm 1206 \\
1427 \pm 386 \\
110 \pm 22\end{array}$ & $\begin{array}{r}555-4133 \\
540-3571 \\
23-250\end{array}$ & $\begin{array}{r}43 \\
8 \\
21 \\
27 \\
5 \\
\end{array}$ & $\begin{array}{r}2599 \pm 455 \\
1048 \pm 346 \\
553 \pm 86 \\
150 \pm 29 \\
254 \pm 110\end{array}$ & $\begin{array}{rr}276-1 & 5870 \\
120- & 2646 \\
100- & 1700 \\
40- & 230 \\
74- & 680\end{array}$ & $\begin{array}{r}43 \\
8 \\
21 \\
7 \\
5 \\
\end{array}$ & $\begin{array}{r}3026 \pm 378 \\
831 \pm 157 \\
566 \pm 92 \\
449 \pm 64 \\
504 \pm 140\end{array}$ & $\begin{array}{r}160-9900 \\
300-1554 \\
60-1620 \\
180-710 \\
130-920\end{array}$ \\
\hline
\end{tabular}

Table 2 Correlation coefficients and significance of ferritin concentrations compared with aminotransferase and liver iron concentrations in patients with iron overload and liver disease

\begin{tabular}{|c|c|c|c|c|c|c|c|}
\hline & & $\begin{array}{l}\text { No of } \\
\text { patients }\end{array}$ & $\begin{array}{l}\text { Total serum } \\
\text { ferritin } \\
\text { concentration } \\
(\mu \mathrm{g} / \mathrm{l})\end{array}$ & $\begin{array}{l}\text { Free ferritin } \\
\text { concentration } \\
(\mu \mathrm{g} / l)\end{array}$ & $\begin{array}{l}\text { Bound ferritin } \\
\text { concentration } \\
(\mu g / l)\end{array}$ & $\begin{array}{l}\% \text { free } \\
\text { ferritin }\end{array}$ & $\begin{array}{l}\text { Total ferritin: } \\
\text { aminotransferase } \\
\text { ratio }\end{array}$ \\
\hline \multirow[t]{4}{*}{$\beta$-thalassaemia major } & $\begin{array}{l}\text { Aminotransferase } \\
\text { IU } / 1\end{array}$ & 43 & $\begin{array}{l}r=0.375 \\
p<0.01\end{array}$ & $\begin{array}{l}r=0.24 \\
N S\end{array}$ & $\begin{array}{l}r=0.414 \\
p<0.01\end{array}$ & $\begin{array}{l}r=0.117 \\
N S\end{array}$ & - \\
\hline & $\begin{array}{l}\text { Liver iron } \\
\text { concentration } \\
\mu \mathrm{g} / 100 \mathrm{~g}\end{array}$ & 8 & $\begin{array}{l}r=0.92 \\
p<0.005\end{array}$ & $\begin{array}{l}r=0.85 \\
p<0.005\end{array}$ & $\begin{array}{l}r=0.93 \\
p<0.001\end{array}$ & $\begin{array}{l}r=0.086 \\
\text { NS }\end{array}$ & $\begin{array}{l}\mathrm{r}=0.31 \\
\mathrm{NS}\end{array}$ \\
\hline & Number of blood & 20 & $r=0.55$ & $r=0.49$ & $r=0.54$ & $r=0.15$ & - \\
\hline & units transfused* & & $p<0.02$ & $\mathrm{p}<0.05$ & $p<0.02$ & NS & - \\
\hline \multirow[t]{3}{*}{ Primary haemochromatosis } & $\begin{array}{l}\text { Aminotransferase } \\
\text { IU } / I\end{array}$ & 8 & $\begin{array}{l}r=0.682 \\
p<0.05\end{array}$ & $\begin{array}{l}r=0.771 \\
p<0.05\end{array}$ & $\begin{array}{l}r=0.112 \\
N S\end{array}$ & $\begin{array}{l}r=0.777 \\
r<0.025\end{array}$ & - \\
\hline & Liver iron & 7 & $r=0.827$ & $r=0.714$ & $r=0.587$ & $r=0.337$ & $r=0.676$ \\
\hline & concentration & & $\mathrm{p}<0.025$ & $0.1>p>0.0$ & $5 \mathrm{NS}$ & NS & $0.1>p>0.05$ \\
\hline \multirow[t]{3}{*}{ Alcoholic liver disease } & Aminotransferase & 21 & $r=0.593$ & $r=0.727$ & $r=0.26$ & $r=0.269$ & - \\
\hline & IU/I & & $p<0.005$ & $\mathrm{p}<0.001$ & NS & NS & - \\
\hline & $\begin{array}{l}\text { Liver iron } \\
\text { concentration }\end{array}$ & 10 & $\begin{array}{l}r=0.30 \\
N S\end{array}$ & $\begin{array}{l}r=0.15 \\
N S\end{array}$ & $\begin{array}{l}r=0.23 \\
N S\end{array}$ & $\begin{array}{l}r=0.08 \\
N S\end{array}$ & $\begin{array}{l}r=0.31 \\
N S\end{array}$ \\
\hline Primary biliary cirrhosis & $\begin{array}{l}\text { Aminotransferase } \\
\text { IU } / 1\end{array}$ & 7 & $\begin{array}{l}r=0.619 \\
0.1>p>0.0\end{array}$ & $\begin{array}{l}r=0.0 \\
50.1>p>0.0\end{array}$ & $\begin{array}{l}r=0.34 \\
5 \mathrm{NS}\end{array}$ & $\begin{array}{l}r=0.188 \\
N S\end{array}$ & - \\
\hline Chronic active hepatitis & $\begin{array}{l}\text { Aminotransferase } \\
\text { IU } / 1\end{array}$ & 5 & $\begin{array}{l}r=0.89 \\
p<0.05\end{array}$ & $\begin{array}{l}r=0.96 \\
p<0.01\end{array}$ & $\begin{array}{l}r=0.682 \\
N S\end{array}$ & $\begin{array}{l}r=0.47 \\
N S\end{array}$ & - \\
\hline
\end{tabular}

$r \quad=$ correlation coefficient

NS $=$ not significant at $5 \%$ level.

* $\quad$ = patients who had not received chelation therapy.

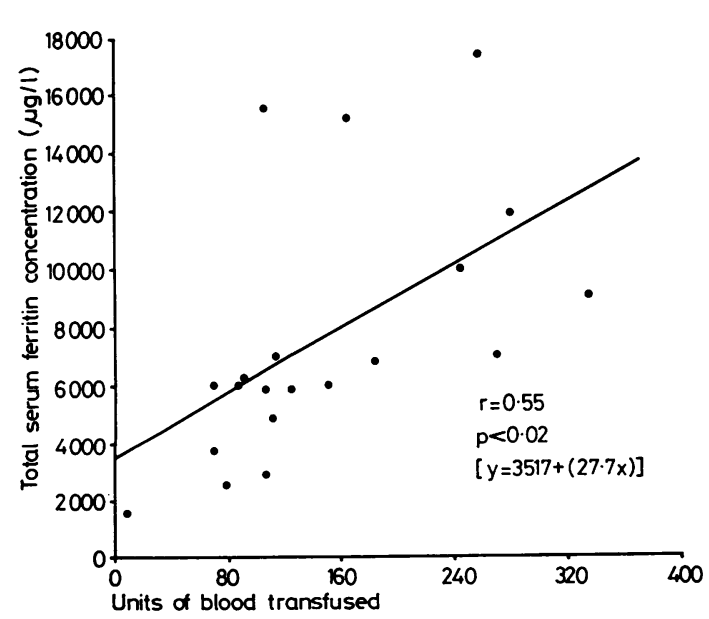

Fig. 1 Total units of blood transfused plotted against the total serum ferritin concentration for unchelated thalassaemic patients.

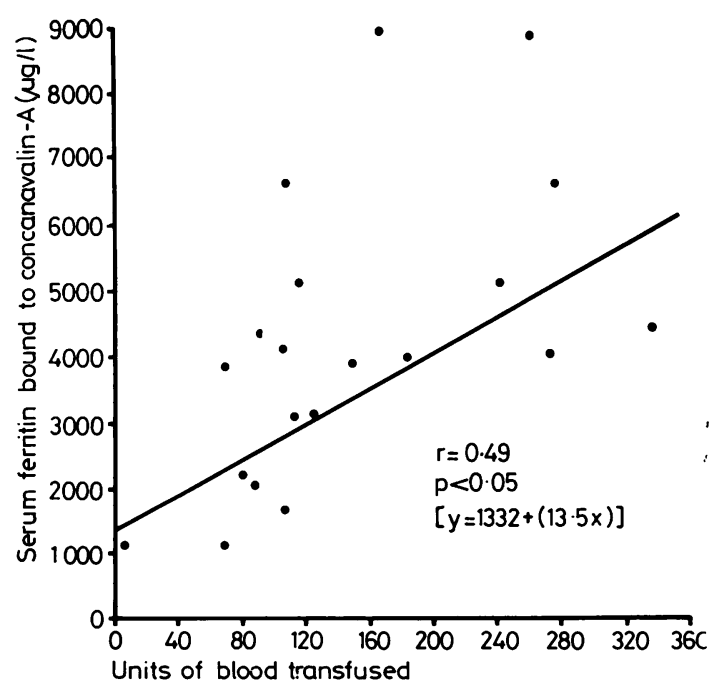

Fig. 2 Total units of blood transfused plotted against the serum ferritin concentration bound to concanavalin $A$ for unchelated thalassaemic patients. 


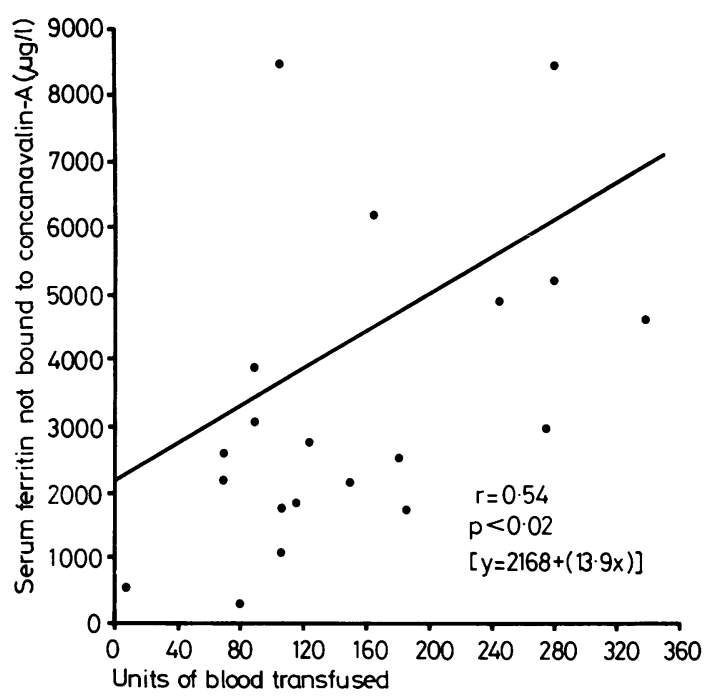

Fig. 3 Total units of blood transfused plotted against serum ferritin concentration not bound to concanavalin A for unchelated thalassaemic patients.

iron overload on the one hand, and those with alcoholic liver disease alone on the other hand (Fig. 4). The patients with iron overload and with

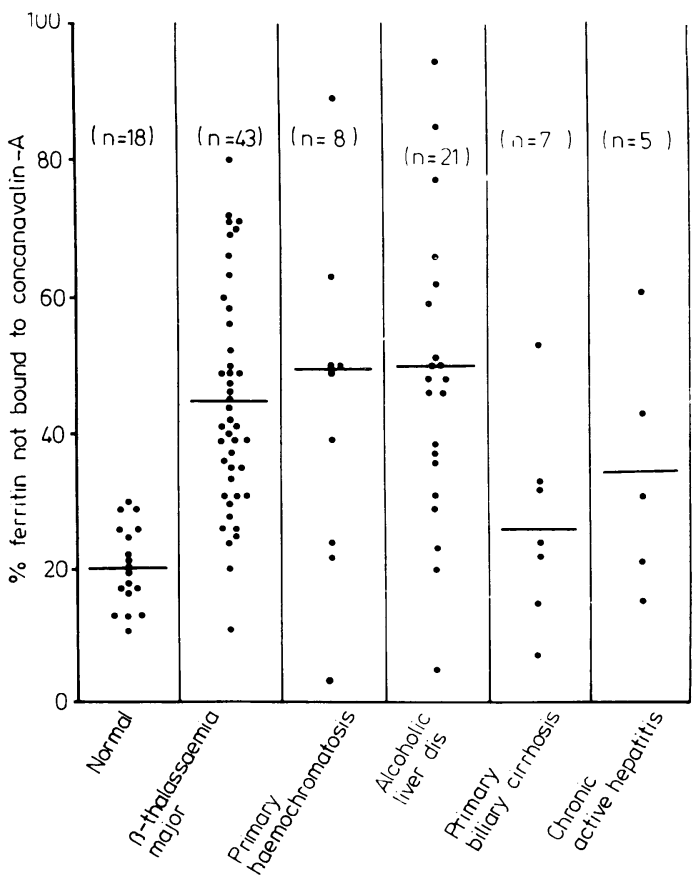

Fig. 4 Ferritin ( $\%$ ) not bound to concanavalin $A$ for the groups studied. The horizontal line represents the mean value of each group. alcoholic liver disease both showed a wide range of results. The means of all three groups were significantly increased compared with the normal controls $(\mathrm{p}<0.05)$ and with patients with primary biliary cirrhosis (p<0.05) (Fig. 4).

VITAMIN C STATUS

The leucocyte ascorbic acid concentration was below the normal range $\left(23-51 \mu \mathrm{g} / 10^{8} \mathrm{WBC}\right)$ in seven of 27 thalassaemic patients tested with a mean value of $31.3 \pm 4.3$ (SEM), and range of 0.6-107 $\mu \mathrm{g} / 10^{8} \mathrm{WBC}$. The mean free ferritin for the seven non-thrombocytopenic ascorbic acid-deficient thalassaemic patients expressed as a percentage was $44.6 \% \pm 2.8$ (SEM) range $33-56 \%$, and did not significantly differ from the ascorbic acid-replete patients (means $43.1 \% \pm 3.9(\mathrm{SEM})$, range $11-80 \%$ ) $(p>0.5)$.

SERUM FERRITIN:AST RATIO

Prieto et $a l^{2}$ showed a close correlation between the serum ferritin:AST ratio and the liver iron concentration in patients with liver disease and in patients with iron overload. They also suggested that a serum ferritin:AST ratio greater than 60 indicates iron overload. Whilst the ferritin:AST ratio did not correlate with the hepatic iron concentration in any of the patients in the present study, no patient with chronic liver disease had a ferritin: AST ratio of greater than 60 , but 34 of 43 thalassaemic patients and four of eight primary haemochromatatic patients did show a greater ratio than 60 (Fig. 5).

\section{Discussion}

This study has confirmed a major contribution of liver damage in determining total serum ferritin concentration in the chronic liver diseases without underlying iron overload. ${ }^{2}$ In addition, we have shown that in both primary and secondary iron overload the "total" serum ferritin is closely related to the degree of hepatic damage as assessed by the serum AST. Similar findings were reported by Worwood et al ${ }^{10}$ in a study of thalassaemic patients. This relationship is probably due to the increasing release of stored intracellular ferritin with increased iron stores and increasingly severe liver damage, but may reflect diminished uptake of circulating ferritin by damaged hepatocytes, as the liver is normally largely responsible for the clearance of serum ferritin. ${ }^{11}$ From this study and that of Worwood et al, 10 it appears that liver damage may be a particularly important factor in determining the total serum ferritin concentration in ironoverloaded patients. 


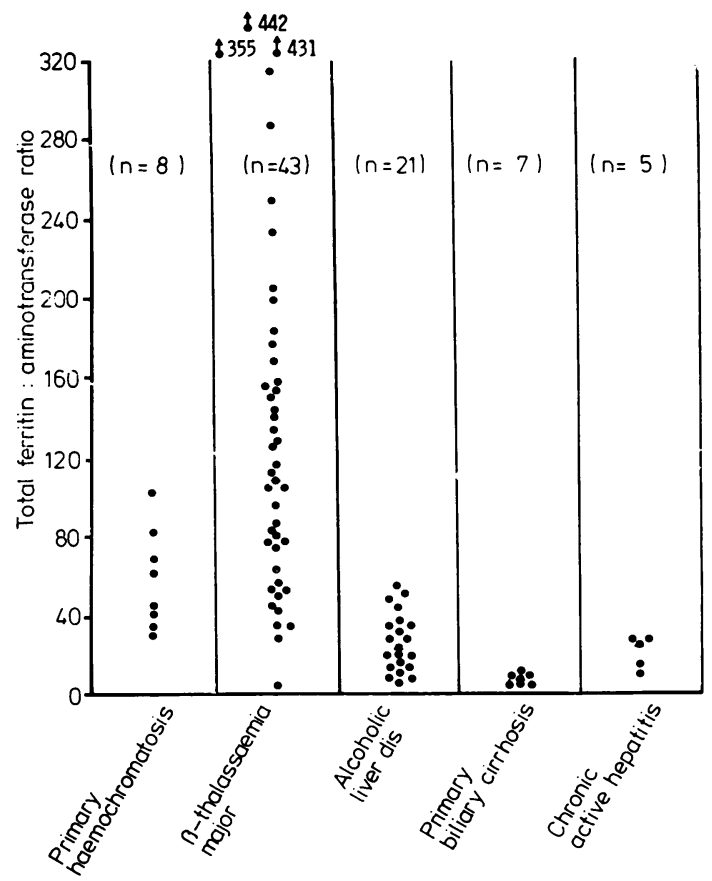

Fig. 5 Total serum ferritin:aminotransferase ratio for the groups studied.

We have also confirmed the correlation between the total serum ferritin and liver iron concentration in patients with primary or secondary iron overload. ${ }^{212}$ For this study we excluded $\beta$-thalassaemic patients with ascorbic acid deficiency as we have recently shown that in $\beta$-thalassaemia major serum ferritin concentrations do not correlate well with liver iron concentration in the presence of ascorbic acid deficiency. ${ }^{13}$

Thus the total serum ferritin in iron overload states is only an indirect measure of total body iron stores and is related to, or affected by, a number of variables, including liver iron concentration, liver damage, ascorbic acid deficiency and probably other factors. Moreover, normal serum ferritin concentrations have been reported in precirrhotic idiopathic haemochromatosis. ${ }^{14}$ It is important, therefore, to estimate the liver iron concentration as an accurate measure of total body iron stores in iron overload states. The liver iron concentration may be estimated from liver biopsy specimens ${ }^{9}$ or by the newer non-invasive technique of $\mathrm{CT}$ scanning. ${ }^{15} 16$

We were unable to show a correlation between ferritin: AST ratio and the liver iron concentration in the iron overloaded patients as was previously reported by Prieto et al. ${ }^{2}$ However, we confirmed their finding that a ferritin:AST ratio of greater than 60 indicates marked iron excess, although iron overload is not excluded by a lower value.

The findings here confirm those of Worwood et $a l^{4}$ that the majority of the various isoferritins present in normal serum bind to the lectin concanavalin $A$. It has been suggested that the ferritin binding to concanavalin $\mathrm{A}$ is glycocylated intracellularly and enters the plasma by secretion rather than by leakage through damaged membranes. ${ }^{4} 17$ If glycosylated ferritin is secreted from cells, it might be expected to be related to liver iron concentration rather than to serum AST which is more a measure of liver damage. In the thalassaemic sera, however, the fraction bound to concanavalin A correlated both with the AST and with the liver iron concentration, and showed a similar correlation as the total serum ferritin with the AST and the liver iron concentration.

The present results also show a correlation in the thalassaemic patients between total serum ferritin, bound ferritin and free ferritin with the total units of blood transfused. However, neither bound nor free ferritin showed a better correlation than the total serum ferritin with the units of blood transfused, confirming the findings of Worwood et al. ${ }^{10}$ Indeed, they found that the bound ferritin showed a worse correlation than the total serum ferritin with the units transfused in thalassaemic patients. ${ }^{10}$ They also demonstrated a relation between bound ferritin and ALT similar to the findings of the present study for bound ferritin and AST. Worwood et al ${ }^{10}$ suggested that in thalassaemic patients the level of glycosylated ferritin reaches a maximum after 100 units of blood have been transfused.

In the sera from patients with primary haemochromatosis it was the free serum ferritin, not bound, in contrast to the thalassaemic patients, which correlated with the liver iron concentration and AST. This difference may be due to an effect of chelation therapy as over half the thalassaemic patients had received desferrioxamine. The total serum ferritin, however, showed the closest correlation with the liver iron. Indeed the percentage of the free ferritin to the total ferritin in the different diseases did not discriminate in evaluating iron excess from liver damage.

Approximately $30 \%$ of alcoholics have increased liver iron stores, ${ }^{18}$ which are not accurately reflected by total serum ferritin concentrations. ${ }^{218}$ While there was a close relation between the free ferritin fraction and the AST, unfortunately none of the ferritin sub-fractions correlated with the liver iron concentration in the alcoholic patients. 
In contrast to the patients with alcoholic liver disease the major proportion of the increased circulating ferritin in patients with chronic active hepatitis and primary biliary cirrhosis studied here was found to be bound to concanavalin $\mathrm{A}$ and did not correlate with serum AST. As there was no evidence of iron overload in these patients, the increase in glycosylated serum ferritin may reflect diminished liver uptake of glycosylated ferritin by damaged liver cells. Halliday et a ${ }^{11}$ have shown that the clearance rate of rat ferritin which is capable of binding to concanavalin $\mathrm{A}$ is significantly slower than the clearance of non-bound ferritin. Interestingly, Birgegard had shown that the major proportion of serum isoferritins circulating during acute infection, as normal sera, bind to concanavalin $\mathrm{A},{ }^{19}$ although in patients with acute hepatic necrosis, the major proportion of circulating ferritin is not bound to concanavalin A. ${ }^{9}$

Ascorbic acid deficiency is known to cause abnormalities in iron and ferritin metabolism, ${ }^{20-23}$. We could not, however, detect any difference in the proportion of serum ferritin binding to concanavalin $A$ between ascorbic acid-deficient and replete thalassaemic patients.

Thus this study has not shown that measuring the serum ferritin fraction binding to concanavalin $A$ is a more useful way of assessing iron stores in patients with liver damage than the total serum ferritin alone. Measuring this fraction does not appear to offer any advantage over total serum ferritin in assessing body iron stores.

\section{References}

${ }^{1}$ Walters GO, Miller FM, Worwood M. Serum ferritin concentrations and iron stores in normal subjects. $J$ Clin Pathol 1973;26:770-2.

${ }^{2}$ Prieto J, Barry M, Sherlock S. Serum ferritin in patients with iron overload and with acute and chronic liver diseases. Gastroenterology 1975;68:525-33.

${ }^{3}$ Worwood M. Serum ferritin. CRC Crit Rev Clin Lab Sci 1979;10:171-204.

4 Worwood M, Cragg SJ, Wagstaff M, Jacobs A. Binding of human serum ferritin to concanavalin A. Clin Sci 1979;56:83-7.

${ }^{5}$ Addison GM, Beamish MR, Hales CN, Hodgkins $M$, Jacobs A, Llewellin P. An immunoradiometric assay for ferritin in the serum of normal subject and patients with iron deficiency and iron overload. J Clin Pathol $1972 ; 25: 326-9$.

- International Committee for Standardisation in Haematology (Iron Panel). The measurement of total and unsaturated iron binding capacity in serum. Recommendation for measurement of serum iron in human blood. Br J Haematol 1978;38:281-94.

${ }^{7}$ Denson KW, Bowers EF. The determination of ascorbic acid in white cells. A comparison of WBC ascorbic acid and phenolic acid excretion in elderly patients. Clin Sci 1961;21:157-62.

${ }^{8}$ Scheuer PJ, Williams R, Muir AR. Hepatic pathology in relatives of patients with haemochromatosis. J Pathol Bacteriol 1962;84:53-64.

${ }^{9}$ Barry M, Sherlock S. Measurement of liver iron concentration in needle biopsy specimens. Lancet 1971;i: 100-3.

${ }^{10}$ Worwood M, Cragg SJ, Jacobs A, McLaren C, Ricketts C, Economidou J. Binding of serum ferritin to concanavalin $A$ : patients with homozygous $\beta$-thalassaemia and transfusional iron overload. $\mathrm{Br} J$ Haematol 1980;46: 409-16.

${ }^{11}$ Halliday JW, Mack U, Powell LW. The kinetics of serum and tissue ferritins: relations to carbohydrate content. Br J Haematol 1979;42:535-46.

12 Letsky EA, Miller F, Worwood M, Flynn DM. Serum ferritin in children with thalassaemia regularly transfused. J Clin Pathol 1974;27:652-5.

${ }^{13}$ Chapman RWG, Hussain MA, Gorman A, Laulicht M, Sherlock S, Hoffbrand AV. Effect of ascorbic acid deficiency on serum ferritin concentrations in patients with $\beta$-thalassaemia major and iron overload. J Clin Pathol 1982; (in press).

${ }^{14}$ Wands JR, Rowe JA, Mezey SE, et al. Normal serum ferritin concentrations in precirrhotic haemochromatosis. N Engl J Med 1976;294:302-5.

${ }^{15}$ Houang MTW, Arozena X, Skalicka A, Huehns ER, Shaw DG. Correlation between computed tomographic values and liver iron content in thalassaemia major with iron overload. Lancet $1979 ;$ i:1322-3.

${ }^{16}$ Chapman RWG, Williams G, Bydder G, Dick R, Sherlock $\mathrm{S}$, Kreel L. Computed tomography for determining liver iron content in primary haemochromatosis. $\mathrm{Br}$ Med J 1980;280:440-2.

17 Cragg SJ, Wagstaff M, Worwood M. Sialic acid and the microheterogenicity of human serum ferritin. Clin Sci $1980 ; 58: 259-62$.

${ }^{18}$ Chapman RW, Laulicht M, Hoffbrand AV, Morgan MY, Sherlock S. Hepatic iron stores and markers of iron overload in alcoholics and patients with haemochromatosis. Dig Dis Sci 1982; (in press).

${ }^{19}$ Birgegard G. The source of serum ferritin during infection. Studies with concanavalin $\mathrm{A}$-sepharose absorption. Clin Sci 1980;59:385-7.

${ }^{20}$ Bothwell TH, Bradlow BA, Jacobs $\mathrm{P}$, et al. Iron metabolism in scurvy with special reference to erythropoiesis. Br J Haematol 1964;10:50-8.

${ }^{21}$ Wapnick AA, Lynch SR, Krawitz P, Seftel HC, Charlton RW, Bothwell TH. Effects of iron overload on ascorbic acid metabolism. Br Med J 1968;iii:704-7.

22 Roeser HP, Halliday JW, Sizemore DJ, Nikles A, Willgoss D. Serum ferritin in ascorbic acid deficiency. Br J Haematol 1980;45:457-66.

${ }^{23}$ Cohen A, Cohen L, Schwartz E. Scurvy and altered iron stores in thalassaemia major. $N$ Engl J Med $1981 ; 304$ : 158-60.

Requests for reprints to: Dr RWG Chapman, Senior Registrar, Department of Medicine and Gastroenterology, John Radcliffe Hospital, Headington, Oxford, England. 